\title{
Kanıta Dayalı Araştırma: Erken Çocukluk Dönemindeki Zihinsel Alanda Üstün Yetenekli Çocuklara Eğitsel Müdahaleler Üzerine Yapılmış Araştırmaların İncelenmesi ${ }^{1}$
}

\author{
Çev. Tuğba Ortaarguna ${ }^{*}$, Feyzullah Şahin ${ }^{\mathrm{b}}$ \\ aDüzce İl Milli Ĕ̆gitim Müdürlüğ̈̈, Düzce. \\ ${ }^{b}$ Düzce Üniversitesi, Eğitim Fakültesi, Özel Ĕ̆itim Bölümü, Düzce.
}

\begin{abstract}
Öz
Son 30 yıllık literatürü içeren bir araştırma, erken çocukluk dönemindeki üstün zekâlı çocuklar (intellectual gifted child) için etkili bir müdahaleyi kapsayan bir araştırmanın eksikliğini ortaya çıkardı. Genç üstün zekâlı çocuklar (young gifted children) için eğitsel hizmetler konulu 11 deneysel çalışmanın bulguları belirlendi ve çalısmaların metodolojik uygunluğu incelendi. Örneklem boyutları, üstün zekâllığın tanımı, deneysel çalışmalardaki zorluklar, üstün zekâlı çocuklarda kullanılan uygun standartlaştırılmış ölçümleri bulma ve programın sonuçlarının ölçümüyle ilgili konularda genç üstün zekâlı çocuklarla yapılan araştırmaların problemli yönleri tartışıldı. Erken çocukluk üstün zekâlılık eğitimi alanı araştırmalarındaki gelecek araştırmaların güçlendirilmesi için önerilerde bulunuldu.
\end{abstract}

Anahtar Kelimeler: Üstün zekâlı eğitimi, Erken çocukluk, Kanıta dayalı uygulama, Eğitsel müdahaleler.

\section{Gíriş}

Genç üstün zekâlı çocuklar eğitimde en az hizmet alan gruplardan biri olarak tanımlanmaktadır (Barbour \& Shaklee, 1998; Chamberlin, Buchanan, \& Vercimak, 2007; Jolly \& Kettler, 2008; Karnes \& Johnson, 1987a; Karnes, Shwedel, \& Linnemeyer, 1982; Koshy \& Robinson, 2006; N. M. Robinson, 2000, 2008). Bu çocukların erken yaşlarda tanılanabildiği (N. M. Robinson, 2008; N. M. Robinson, Abbott, Berninger, Busse, \& Mukhopadhyay, 1997; Smutny, 1999) ve onların eşsiz öğrenme özelliklerini karşılayan bir müfredata erişmeye ihtiyacı oldukları (Maker, 1986; Maker \& Schiever, 2005; N. M. Robinson, Reis, Neihart, \& Moon, 2002) üzerinde görüş birliği olduğu görülürken, genç üstün zekâlı çocuklarda en başarılı olan eğitsel müdahale türlerini bugüne kadar belirleyen çok az araştırma vardır (Jolly \& Kettler, 2008; N. M. Robinson, 2000, 2008). Bu grupta başvurulan araştırma, onların yeteneklerini geliştirmek ve desteklemek için en etkili olan öğretim tekniklerinin belirlenmesinden çok, tanılama üzerine odaklanmaktadır (Meador, 1994; N. M. Robinson, 2000).

Bu makalenin amacı, erken çocukluk dönemindeki üstün zekâlı çocuklar için etkili eğitsel hizmetler konusunda sürdürülmüş araştırmaları incelemektir. Bu çocuklarda yürütülen araştırmaların metodolojik uygunluğunun analizi, hangi eğitsel

\footnotetext{
${ }^{1}$ Walsh, R. L., Kemp, C. R., Hodge, K. A.,\& Bowes, J. M. G. (2012). Searching for evidence-based practice: A review of the research on educational interventions for intellectually gifted children in the early childhood years, Journal for the Education of the Gifted, 35(2), 103-128 adlı çalışmanın çevirisidir.
} 
müdahalelerin genç üstün zekâlı çocuklar üzerindeki verimliliğin kesin bir kanitı olduğunu belirlemeye çalışmaktadır. "Üstün Zekâlı Eğitiminde En İyi Uygulamalar: Kanıta Dayalı Bir Rehber", adlı kitapında A. Robinson, Shore ve Enerson (2007), eğitimcilerin ve ailelerin ulaşabileceği öncelikli ihtiyaçları ve katı bir araştırma tabanına sahip olan üstün zekâlı eğitimindeki uygulamaları vurgulamışlardır. Ancak, üstün zekâlılığın erken belirlenmesinin gerektirmesine rağmen özellikle erken yaşlarda üstün zekâlı çocuklarla alakalı birkaç eğitsel uygulamayı tanımlamışlardır.

Üstün zekâlı eğitiminde araştırmaları içeren önceki incelemeler, özellikle erken çocukluk döneminde deneysel çalışmaların eksikliğini göstermektedir (Johnsen \& Ryser, 1996; Jolly \& Kettler, 2008; White, Fletcher-Campbell, \& Ridley, 2003; Ziegler \& Raul, 2000). Üstün zekâlı eğitimi ile ilgili 1994 ve 2003 yılları arasında yayınlanmış araştırma makalelerini inceleyen, Jolly ve Kettler (2008), çalışmaların büyük çoğunluğunda etkililiğe ilişkin hiçbir destekleyici veri olmadan eğitimsel yaklaşımların tanımlanarak sunulduğunu (\% 83,6), sadece \% 5,5'inin deneysel ve yarı deneysel olduğunu belirlemişlerdir. Bu incelemede, çalışmaların sadece \%1,75'i okul öncesi yaşlardaki çocukları içermekteydi. Benzer olarak, Johnsen ve Ryser (1996), genel eğitim düzenlemelerinde üstün zekâlı öğrencilerle eğitsel uygulamaların verimliliğini inceleyen 1989'dan 1996'ya kadar olan sürede sadece 39 çalışmayı tespit etmişlerdir. Bunlardan da sadece \%39'unun deneysel ya da yarı deneysel yöntem kullandığı rapor edilmiştir.

Jolly ve Kettler (2008), üstün zekâlı eğitiminde uygulama geliştirmek için sadece üstün zekâlılığın tanımlanmasından en etkili uygulamaları değerlendirme ve doğrulamaya doğru bir değişikliğe ihtiyaç olduğu sonucuna varmışlardır. White ve meslektaşları (2003), üstün zekalıların eğitimde kanıta dayalı uygulama ve politika eksikliği ve deneysel çalışmaların azlığının, sadece uygulayıcıların deneyimlerini yansıttı̆̆ı literatür anlamına geldiğini belirtmişlerdir. Uygulama deneyimi yararlı olurken deneysel araştırma eksikliğinin, kendi kendini yenileyebilir hale gelme ve diğer olası eğitimsel seçenekleri göz önünde bulundurmayan tek bir bakış açısını yansıtma tehlikesini barındırdığını kabul ettiler.

Erken çocukluk dönemi üstün zekâlı eğitimindeki güncel uygulamalar, genç üstün zekalı çocuklarda başarılı olması gereken eğitsel müdahalelerin, bu çocuklara sunulan genişletilmiş müfredat seçeneklerinin süreçleri zenginleştirme; daha erken yaşlarda ve/veya resmi okula erken başlamada istenilen materyalin sunumunu içeren hızlandırma ve hem eğitimsel hem de sosyo-duygusal amaçlar için benzer zeka düzeyindeki çocukların beraber yerleştirilmesi anlamına gelen yetenek gruplandırmasını kapsayan eğitsel müdahaleleri önermektedir. Erken çocukluk dönemi eğitimi ile ilgili şu anki durum, genç üstün zekâlı çocuklara bu tür müdahalelerde yapısal olarak birlikte çalışmak için üstün zekâlı eğitimi ve erken çocukluk dönemi alanlarında çalışanların çok fazla olanağı olduğunu göstermektedir (Walsh, Hodge, Bowes, \& Kemp 2010).

Bu makalede erken çocukluk dönemindeki üstün zekâlı çocuklarla başlatılmış müdahale çalışmalarına genel bir bakışı sunulmaktadır ve araştırma planlarının sınırlı 
ve güçlü yönleri tanımlanmaktadır. Böyle bir eleştiriye ihtiyaç duyulmaktadır. Çünkü genç üstün zekâlı çocuklarla çalışanların kanıta dayalı eğitimsel uygulamanın ne olduğunu belirleme gereksiniminin artması, programın verimliliğini gösteren verilerle birlikte programları doğrulayabilmelidir. Eğitimcilerin ve politikacıların, genç üstün zekâlı çocuklara uygun olan araştırmaların güvenirlik ve uygunluğu hakkında bilgilendirici kararlar alabilmeye ihtiyacı vardır. Özel bir müdahaleye tamamen karşı çıkan bakış açılarını destekleyen araştırmalar sıkça bulunabilir (örneğin yeteneklerine göre gruplandırılmış çocuklarla ilgili bir araştırma) ve sadece araştırma metodolojisinin dikkatli incelenmesi, araştırmadaki olası hataları belirler. Bugüne kadar, erken çocukluk dönemindeki üstün zekâlı çocuklar için eğitimsel müdahaleler üzerine özellikle odaklanmış herhangi bir inceleme yoktur.

\section{METOD}

\section{Araştırma Prosedürleri}

Verilere, ERIC (Eğitim Kaynakları Bilgi Merkezi) ve PsycInfo (Amerikan Psikolojik Derneği verileri) veri tabanından, üstün zekal,, üstün yetenekli, yüksek yetenek; erken çocukluk, okul öncesi, anaokulu, okuldan önce; eğitim, öğretim ve müdahale anahtar sözcükleri kullanılarak ulaşılmıştır. Ayrıca, üstün zekalı eğitiminde yayın yapan başlica Gifted Child Quarterly(GCQ), Journal for the Education of the Gifted (JEG) ve Rooper Review(RR) gibi uluslar arası dergilerin indeksleri taranmıştır.

\section{Seçim Kriterleri}

$\mathrm{Bu}$ araştırmaya bir yayının belli ölçütlerini karşılayan çalışmalar dâhil edilmiştir. İlk olarak, son 30 yılda hakemli bir dergide yayınlanmış bir makale olmak şartı aranmıştır. Yakın zamanlarda çok az araştırma olmasından dolayı, 30 yıl kadar gerideki yayınların incelenmesine karar verildi. Hakemli araştırma tercihi, araştırmanın kalite düzeyini arttırmıştır.

İkinci olarak, raporlanan araştırmalar okuldan önceki erken yıllara ve resmi eğitimin ilk yılındaki çocuklara odaklanmak zorundaydı. Erken çocukluk yıllarında gerçekleştirilmiş olan müdahaleleri takip eden boylamsal araştırmalar haricinde, altı yaşın üzerindeki çocukları içeren çalışmalara yer verilmedi.

Üçüncü olarak, bu çalışma üstün zekalı çocuklarda kullanılan eğitimsel müdahaleler üzerinde verimlilik ve etkililik verilerini içermek zorundaydı. İlgi çekici ve potansiyel olarak etkili müdahaleleri anlatan, fakat hiç etkililik verileri olmayan çalışmalara yer verilmemiştir (Örneğin; Coates, Thompson, \& Shimmin, 2008; Diezmann \& English, 2001; Diezmann \& Watters, 1997; Hensel, 1991; Hertzog, Klein, \& Katz, 1999; Morgan, 2007; Rosenbusch \& Draper, 1985).

Toplamında, belli ölçütleri karşılayan 11 çalışma belirlenmiş (yayın detayları ve çalışmaya katılanlar, müdahaleler ve müdahale sonuçları ve önemli bulguları içeren detaylar için Tablo 1'e bakınız), bunlar kaynakça bölümünde yıldız işaretleri ile işaretlenmiştir. 


\section{Çalışmalara Genel Bakış}

Seçilen çalışmalar çok çeşitli müdahaleleri içermektedir (bakınız, Tablo 1). Bazı çalışmalar, matematik (N. M. Robinson vd., 1997), sinektik (Meador, 1994) ve anolojiler (Castillo, 1998) gibi belli bir konuda eğitimi sunmaktadır. Diğerleri, tam zamanlı veya yarı zamanlı, bağımsız okul öncesi programları (Karnes \& Johnson, 1987a, 1987b; Karnes, Shwedel \& Lewis, 1983a, 1983b; VanTassel-Baska, Schuler \& Lipschutz, 1982) veya ilköğretime erken başlama (Gagne \& Gagnier, 2004; Obrzut, Nelson \& Obrzut, 1984) gibi sistematik program veya yetenek gruplama müdahalelerini sunmaktadır.

Çalışmalardan 10'u Birleşik Devletler'de, bir tanesi de Kanada'da yürütülmüştür. Çalışmalar, en az 20 uygulama (Castillo, 1998), okulöncesi üstün zekalı çocuklardan oluşan sınıflardaki iki yıllık süre (Karnes \& Johnson, 1987a) veya 4 yaş üstü okula erken başlayanlarla (Obrzut vd., 1984) sürdürülen boylamsal çalışmalar gibi farklı aralıkta yer almaktaydı.

Bütün çalışmalar erken çocukluk yaş aralığındaki çocukları kapsamaktadır (Tablo 1). Çalışmaların altısı, okul öncesindeki gruplardaki çocukları kapsamaktadır. Üstün zekalılığı belirlemek için çok çeşitli ölçümler kullanılmıştır (Bakınız: Tanılama kriterleri, Tablo 2). Bunlar, IQ testi, bağıl yetenek ve başarı testinin diğer türleri ve ebeveyn ve öğretmen görevlendirmelerini içermiştir. Çalışmalar, kullanılan araçlarda ve üstün zekalı olduğu düşünülen bir çocuğun seviyesinde oldukça çeşitlilik göstermiştir. Castillo (1998) seçme kriterleri bildirmemiş ve okul tarafından üstün zekalı olarak belirlenen bir örneğin kullanıldığını bildirmiştir.

Örnek ölçüler, Tablo 2'de gösterildiği gibi, 14 çocuktan (VanTessel-Baska vd., 1982) 1821 çocuğa (Gagne \& Gagnier, 2004) kadar uzanmaktadır. Sadece iki çalışmada (Castillo, 1998; N.M. Robinson vd., 1997) rastgele örneklemenin bazı türlerini kullandığını görülmüştür.

Bağımlı değişkenleri ölçmek için çok sayıda araç kullanılmıştır (bknz., Tablo 1). Bunlar, Stanford-Binet IV (Thorndike \& Sattler, 1986) gibi IQ testlerini; Yaratıc1 Düşünme Torrance testi (Torrance, 1998) gibi yaratıcı ve 1raksak düşünme testler; ölçüt bağımlı akademik başarı testleri ve araştırmacı tarafından geliştirilen materyalleri içermektedir. 
Tablo 1. İncelemede Yer Alan Çalışmaların Seçim Özellikleri

\begin{tabular}{|c|c|c|c|c|c|}
\hline $\begin{array}{l}\text { Yazar(lar)/ } \\
\text { Dergiler }\end{array}$ & $\begin{array}{l}\text { Çocukların } \\
\text { Yaşları }\end{array}$ & $\begin{array}{l}\text { Müdahale } \\
\text { Odağı }\end{array}$ & Bağımlı Değişken & Ölçümler & Önemli Bulgular \\
\hline $\begin{array}{l}\text { Castillo (1998) } \\
\text { Reoper Review }\end{array}$ & $5-6$ yaş & Analojiler & $\begin{array}{l}\text { Analoji } \\
\text { tanimlama, } \\
\text { Yanit açıklama, } \\
\text { Metoforu } \\
\text { yorumlama } \\
\end{array}$ & $\begin{array}{l}\text { Analojileri açılamaya yönelik } \\
\text { araştırıcı tarafından geliştirilmiş } \\
\text { testler, yanıtlara ilişkin kanı ve } \\
\text { metaforların yorumu }\end{array}$ & $\begin{array}{l}\text { Analoji müdahalesi çocuklarda yapılan metaforları anlamayı anlamlı } \\
\text { düzeyde geliştirmiştir. }\end{array}$ \\
\hline $\begin{array}{l}\text { Gagné ve Gagnier } \\
\text { (2004) } \\
\text { Reoper Review }\end{array}$ & $\begin{array}{l}\text { Anaokulu ve } 2 \\
\text { sinif }\end{array}$ & $\begin{array}{l}\text { Okula erken } \\
\text { başlama }\end{array}$ & $\begin{array}{l}\text { Sosyo-duygusal } \\
\text { uyum ve } \\
\text { akademik başarı }\end{array}$ & $\begin{array}{l}\text { Quay (1979) tarafından } \\
\text { geliştirilmiş olan problem } \\
\text { davranışları belirlemeye dayalı } \\
\text { yazarlar tarafından geliştirilmiş } \\
\text { öğretmen dereceleme ölçeği } \\
\text { kullanımı }\end{array}$ & $\begin{array}{l}\text { Erken kayıt olanlarla zamanında kayı olan öğrenciler arasında, } \\
\text { başvurulan ölçekler, sosyal entegrasyon, akademik olgunluk ve akademik } \\
\text { başarı açısından önemli bir fark yoktur. Yarı nitel analizler, ögretmenlerin } \\
\text { erken kayıt olanların önemli oranının uyum sorununun olduğu } \\
\text { kanaatinde olduğunu ortaya çkarmışır. }\end{array}$ \\
\hline $\begin{array}{l}\text { Hanninen (1984) } \\
\text { Journal for the } \\
\text { Education of the Gifted }\end{array}$ & $3-5$ yaş & $\begin{array}{l}\text { Kavram değer- } \\
\text { lendirme ve } \\
\text { müfredat planı }\end{array}$ & Yaratıcilık & $\begin{array}{l}\text { PIAT, Torrance Yaratıc1 } \\
\text { Düşünme Testi (TYDT) }\end{array}$ & $\begin{array}{l}\text { PIAT'ta matematik ve okumada ortaya çlkmamıştır, fakat genel bilgi } \\
\text { kategorisinde anlamlı sonuçlar. Daha yüksek yaratıcılık, akıcllık ve okul } \\
\text { öncesi katılımcılar için daha yüksek orjinallik puanı. }\end{array}$ \\
\hline $\begin{array}{l}\text { Karnes and Johnson } \\
\text { (1978b) } \\
\text { Gifted Child Quarterly }\end{array}$ & $\begin{array}{l}\text { Belirtilmemiş, } \\
\text { fakat çocuklar } \\
\text { okul öncesi } \\
\text { dönem } \\
\text { çocukları. }\end{array}$ & BOHST & Yaraticilık & $\begin{array}{l}\text { Eylem ve Harekette Yaratıc1 } \\
\text { Düşünme (Torrance,1981), K- } \\
\text { ABC'nin } 4 \text { alttesti (Kaufman \& } \\
\text { Kaufman, 1982; sihirli halkalar, } \\
\text { yüz tanıma, Gestalt kapama ve } \\
\text { açılayıcı sözcükler), Öz-benlik } \\
\text { algısı ve motivasyon envanteri } \\
\text { (Milchus, Farrah, \& Reitz, 1967) }\end{array}$ & $\begin{array}{l}\text { Müdahale edilen çocuklarda, kontrol grubundakilerden daha iyi } \\
\text { performans. En büyük kazanımlar potansiyel olarak üstün zekalı diye } \\
\text { tanımlananlarda değil müdahale edilen çocuklar tarafından elde edildi. } \\
\text { Müdahale grubu öğretmenler sınıfların, kontrol grubu öğretmenlerden } \\
\text { daha pozitif olarak tanımlamıştır. }\end{array}$ \\
\hline $\begin{array}{l}\text { Karnes and Johnson } \\
\text { (1987a) } \\
\text { Journal for the } \\
\text { Education of the Gifted }\end{array}$ & $3-5$ yaş & $\begin{array}{l}\text { Guilford'un Ze- } \\
\text { ka Yapısı (SOI) } \\
\text { ve British Infant } \\
\text { School'un tam } \\
\text { zamanlı okul } \\
\text { öncesi şeması } \\
\end{array}$ & $\begin{array}{l}\text { Okuma } \\
\text { Matematik }\end{array}$ & $\begin{array}{l}\text { Başarı ve Eğitim Yetenekleri } \\
\text { Serisi (Science Research } \\
\text { Associates Inc, 1985). Öğretmen } \\
\text { ve aile raporu. }\end{array}$ & Çocuklarda ölçülebilen kazanımlar her bir programı kapsamıştır. \\
\hline $\begin{array}{l}\text { Karnes, Shwedel and } \\
\text { Lewis (1983a) } \\
\text { Journal for the } \\
\text { Education of the Gifted }\end{array}$ & $\begin{array}{l}\text { Okul öncesi } \\
\text { dönem (sınıf 4'ü } \\
\text { takip eden) }\end{array}$ & RAPYHT & $\begin{array}{l}\text { Okuma ve } \\
\text { Matematik }\end{array}$ & $\begin{array}{l}\text { Standardize edilmiş ulusal } \\
\text { başarı testleri, öğretmen anketi }\end{array}$ & $\begin{array}{l}\text { Bütün ölçümlerde RAPYHT çocukları yeni aktiviteleri denemeye istekli } \\
\text { olanlar sınıf arkadaşları haricinde üstün olarak sınıflandırılmıştır. }\end{array}$ \\
\hline $\begin{array}{l}\text { Karnes,Shwedel and } \\
\text { Lewis (1983b) }\end{array}$ & $\begin{array}{l}\bar{X}=4.4 \text { yaş (üstün } \\
\text { zekalı) }\end{array}$ & RAPYHT & $\begin{array}{l}\text { Yetenek } \\
\text { alanlarının }\end{array}$ & $\begin{array}{l}\text { Animal Crackers'dan iki alttest } \\
\text { (Adkins \& Ballif, 1973), Eylem }\end{array}$ & $\begin{array}{l}\text { Üstün zekalı çocuklardan oluşan deney grubu müdahale al } \\
\text { beklenilenden daha yüksek performans sergilemişlerdir. }\end{array}$ \\
\hline
\end{tabular}


T. Ortaargun, F. Şahin / Karabük Üniversitesi Sosyal Bilimler Enstitüsü Dergisi, 2015, 5 (2), 300-322

\begin{tabular}{|c|c|c|c|c|c|}
\hline Exceptional Children & $\begin{array}{l}\bar{X}=4.3 \text { yaş (üstün } \\
\text { zekalı olmayan) }\end{array}$ & & $\begin{array}{l}\text { işlevselleştirilmesi, } \\
\text { öz-benlik algısı, } \\
\text { yaratıcılık ve } \\
\text { görevde ısrarcılık }\end{array}$ & $\begin{array}{l}\text { ve Harekette Yaratıcı Düşünme } \\
\text { (Torrance, 1981), Yetenek } \\
\text { Değerlendirme Kontrol Listesi } \\
\text { (Karnes, Brown, Shwedel \& } \\
\text { Svoboda, 1980) }\end{array}$ & \\
\hline $\begin{array}{l}\text { Meador (1994) } \\
\text { Journal for the } \\
\text { Education of the Gifted }\end{array}$ & $\bar{X}=5.7$ yaş & Sinektik & $\begin{array}{l}\text { Yaratıcılık, öz- } \\
\text { benlik algısı ve } \\
\text { sözel beceriler }\end{array}$ & TYDT, MZSCS ve PPVT & $\begin{array}{l}\text { PPVT ve MZSCS puanlarında deney ve kontrol gruplarında önemli bir } \\
\text { fark saptanamamıstır. Deney grubu, Sinektik eğitiminin yaratıc1 } \\
\text { düşünceyi geliştirdiğini göstererek TYDT'de kontrol grubundan } \\
\text { istatistiksel olarak daha iyi sonuç aldı. Üstün zekalı olan ve üstün zekalı } \\
\text { olmayan çocuklarda benzer etkiyi göstererek her iki grup arasında fark } \\
\text { bulunmamıștır. }\end{array}$ \\
\hline $\begin{array}{l}\text { Obrzut, Nelson ve } \\
\text { Obrzut (1984) } \\
\text { Psychology in the } \\
\text { Schools }\end{array}$ & $\begin{array}{l}\text { Okula başlama } \\
\text { yaş1 } 4.8-5.11\end{array}$ & $\begin{array}{l}\text { Okula erken } \\
\text { başlama }\end{array}$ & $\begin{array}{l}\text { Akademik başarı } \\
\text { (okuma, yazma, } \\
\text { matematik) ve } \\
\text { okula alışma }\end{array}$ & $\begin{array}{l}\text { WRAT, okul kayıtları, sağlık } \\
\text { kayıtları, Aile-Öğretmen } \\
\text { akademik düşünce anketi ve } \\
\text { görüşmeler }\end{array}$ & $\begin{array}{l}\text { Okula erken kayıt yaptıran çocuklar, okuma, yazma ve matematik } \\
\text { ölçümlerinde önemli derecede daha iyi performans sergiler. Sosyal } \\
\text { olgunluk ölçümlerindeki gruplar arasında önemli farklllıklar yoktur. } \\
\text { Toplaminda, erken kayıt olanları \% } \% 8^{\prime} i \text {, normal zamanda okula } \\
\text { başlayan çocukların sadece } \% 2 \text { 'si ile kıyaslandığında okulun ilk } 4 \text { yllında } \\
\text { devam ettirmiştir. }\end{array}$ \\
\hline $\begin{array}{l}\text { N. M. Robinson, } \\
\text { Abbott, Berninger, } \\
\text { Buse and } \\
\text { Mukhopadhyay } \\
\text { (1997) } \\
\text { Gifted Child Quarterly }\end{array}$ & $\begin{array}{l}\bar{X}=5.5-8.0 \text { yaş } \\
\text { (Çalışma iki } \\
\text { yıldan fazla } \\
\text { sürmüştür) }\end{array}$ & $\begin{array}{l}\text { Matematikte } \\
\text { zenginleştirme }\end{array}$ & $\begin{array}{l}\text { Görsel-uzamsal } \\
\text { mantık ve } \\
\text { matematiksel } \\
\text { yetenek }\end{array}$ & $\begin{array}{l}\text { Stanford-Binet IV (Sayı dizileri, } \\
\text { sayısal, kelime, anlama, cümle } \\
\text { bellekleri, örnek analizleri ve } \\
\text { Matrisler alt testleri) Key Math } \\
\text { Test-Revised (Geometri, sayılar, } \\
\text { problem çözme alt testleri), } \\
\text { Woodcock-Johnson Achivement } \\
\text { Test-revised (Aritmetik alt testi), } \\
\text { Kelime Problemleri Testi, Sayı } \\
\text { Bilgisi Testi, Açıklık Hesaplama } \\
\text { Testi, Görsel Uzamsal Açıklık } \\
\text { Testi }\end{array}$ & $\begin{array}{l}\text { Müdahalenin sonundaki sayısal ve sözel faktörler arasındaki daha yüksek } \\
\text { korelasyon kadar; sayısal alanda, müdahale grubunda daha yüksek } \\
\text { puanlar. }\end{array}$ \\
\hline $\begin{array}{l}\text { Van Tassel-Baska, } \\
\text { Schuler and Lipschutz } \\
\text { (1982) } \\
\text { Journal for the } \\
\text { Education of the Gifted }\end{array}$ & $4.1-4.10$ yaş & $\begin{array}{l}\text { Bireyselleştiril- } \\
\text { miş akademik } \\
\text { program }\end{array}$ & $\begin{array}{l}\text { Matematik ve } \\
\text { okuma, kelime } \\
\text { öğrenme }\end{array}$ & $\begin{array}{l}\text { WRAT, PPVT, Raven's CPM, } \\
\text { Aile Görüşmeleri }\end{array}$ & $\begin{array}{l}1 \text { yll ve daha fazla sürede WRAT alt test skorlarında artış (okumada \%35, } \\
\text { matematikte \%85). PPVT'de \% 10'luk puanların ve daha fazla artıs (\%64) } \\
\text { 80. yüzdelik değerlerdeki veya Raven's CPM (\%64) veya ilk \%80'lik dilim } \\
\text { içerisinde yer alma. Ailelerin anlatım değerlendirmesi olumlu öğrenci } \\
\text { tutumlarının gelişimini (\%100) göstermiş̧ir. }\end{array}$ \\
\hline
\end{tabular}

Note: PIAT = Peabody Individual Achievement Test; BOHST = Bringing Out Head Start Talents; K-ABC = Kaufman Assessment Battery for Children; SOI =Structure of the Intellect; RAPYHT = Retrieval and Acceleration of Promising Young Handicapped and Talented; MZSCS = Martinek-Zaichkowsky Self-Concept Scale; PPVT = Peabody Picture Vocabulary Test; WRAT = Wide Range Achievement Test; CPM = Colored Progressive Matrices. 
T. Ortaargun, F. Şahin / Karabük Üniversitesi Sosyal Bilimler Enstitüsü Dergisi, 2015, 5 (2), 300-322

Tablo 2. İncelemede Yer alan Çalışmaların Araştırma Tasarımı

\begin{tabular}{|c|c|c|c|c|c|}
\hline Çalışma & $\begin{array}{l}\text { Örnek } \\
\text { Boyutu }\end{array}$ & $\begin{array}{l}\text { Araştırma } \\
\text { Planı }\end{array}$ & Kontrol / Karşılaştırma Grubu & Üstün Zekalılığın Tanımı & Çocukların Tanılanması \\
\hline $\begin{array}{l}\text { Castillo } \\
(1998)\end{array}$ & $\mathrm{N}=63$ & $\begin{array}{l}\text { Tam } \\
\text { deneysel }\end{array}$ & $\begin{array}{l}\text { Evet - Üstün zekalı olmayan } \\
\text { çocuklar }\end{array}$ & Belirtilmemiş & $\begin{array}{l}\text { Üstün zekalı çocuklar için bir okula kayıt olma- özel bir kriter } \\
\text { belirtilmemiştir. }\end{array}$ \\
\hline $\begin{array}{l}\text { Gagné and Gagnier } \\
\text { (2004) }\end{array}$ & $\begin{array}{l}\mathrm{n}=98 \text { (erken } \\
\text { başlayanlar) } \\
\mathrm{n}=1.723\end{array}$ & $\begin{array}{l}\text { Deneysel } \\
\text { değil }\end{array}$ & $\begin{array}{l}\text { Evet - Normal olarak kabul } \\
\text { edilen öğrenciler }\end{array}$ & Belirtilmemiş & $\begin{array}{l}\text { Erken kayıtlılar için zeka yaşı } 5 \text { yıl } 9 \text { ay. Ekim doğumlu } \\
\text { çocukların } 117 \text { IQ'suna denk. }\end{array}$ \\
\hline $\begin{array}{l}\text { Hanninen } \\
(1984)\end{array}$ & $\mathrm{N}=66$ & $\begin{array}{l}\text { Karma } \\
\text { metot }\end{array}$ & $\begin{array}{l}\text { Hayır - Fakat okul öncesi } \\
\text { programda olmayan 3örnek } \\
\text { çocuk Slosson IQ'suna } \\
\text { dayanarak eşleştirildi. }\end{array}$ & $\begin{array}{l}\text { Dil gelişimi, bilişsel yetenek, sosyal } \\
\text { beceriler, fiziksel kapasite, yaratıcılık } \\
\text { ve liderlik gibi birçok alanda yaş } \\
\text { sinırı üstünde performans sergileyen } \\
\text { bir okul öncesi üstün zekalı ve } \\
\text { yetenekli çocuk olarak düşünülebilir } \\
\text { (sf. 193) }\end{array}$ & $\begin{array}{l}\text { Çoklu kriter: PPVT, CMMS ve/ veya Goodenough-Harrison } \\
\text { Testi ortalaması üstünde } 1.5 \text { standart sapma, Aile görüşmesi }\end{array}$ \\
\hline $\begin{array}{l}\text { Karnes and Johnson } \\
(1987 b)\end{array}$ & $\mathrm{N}=446$ & $\begin{array}{l}\text { Karma } \\
\text { metot }\end{array}$ & Evet & Belirtilmemiş & $\begin{array}{l}\text { Çoklu Kriter: Öğretmen kontrol listesi, Aile kontrol listesi ve } \\
\text { yetenek tanımlayıcı özet. }\end{array}$ \\
\hline $\begin{array}{l}\text { Karnes and Johnson } \\
\text { (1987a) }\end{array}$ & $\mathrm{N}=31$ & $\begin{array}{l}\text { Karma } \\
\text { metot }\end{array}$ & $\begin{array}{l}\text { Benzer yetenekteki akranlarıyla } \\
\text { eşleşen çocukların eğitsel } \\
\text { yetenek oranında beklenen } \\
\text { kazanımlara dayandırılır. }\end{array}$ & Normalden 1.5 standart sapma & $\begin{array}{l}\text { Çoklu Kriter: Aile anketi ve entelektüel ince motor } \\
\text { değerlendirmesi ve yaratıcı çalışma }\end{array}$ \\
\hline $\begin{array}{l}\text { Karnes ve meslektaşları } \\
\text { (1983a) }\end{array}$ & $\mathrm{N}=30$ & $\begin{array}{l}\text { Karma } \\
\text { metot }\end{array}$ & $\begin{array}{l}\text { Hayır, fakat çocuklar sınıf } \\
\text { arkadaşları ve ulusal örneklerle } \\
\text { karşılaştırıldı. }\end{array}$ & Marland (1972) & $\begin{array}{l}\text { Yetenek tarama kontrol listesi, Yetenek tanımlama } \\
\text { aktiviteleri, Tanımlama ve gerekirse psikolog ile takip. }\end{array}$ \\
\hline $\begin{array}{l}\text { Karnes ve meslektaşları } \\
\text { (1983b) }\end{array}$ & $\begin{array}{l}\mathrm{n}=28 \\
\text { (deney) } \\
\mathrm{n}=8 \text { kontrol) }\end{array}$ & $\begin{array}{l}\text { Karma } \\
\text { metot }\end{array}$ & Evet & Marland (1972) & Öğretmen Dereceleme Yetenek Belirleme Kontrol Listesi \\
\hline Meador (1994) & $\begin{array}{l}\mathrm{n}=23 \\
\text { (deneysel) } \\
\mathrm{n}=41 \\
\text { (kontrol) }\end{array}$ & $\begin{array}{l}\text { Yarı } \\
\text { deneysel }\end{array}$ & $\begin{array}{l}\text { Evet - Hem üstün zekalı hem de } \\
\text { üstün zekalı olmayan deney ve } \\
\text { kontrol grubu }\end{array}$ & Belirtilmemiş & $\begin{array}{l}\text { Okul bölgesi tarafından başvurulan iki aşamalı tarama süreci. } \\
\text { Öğrenci görüşmesi, veli anketi, KBIT ve Einsten Hazırlık testi } \\
\text { uygulanmıştır. }\end{array}$ \\
\hline $\begin{array}{l}\text { Obrzut ve meslektaşları } \\
\text { (1984) }\end{array}$ & $\mathrm{N}=68$ & 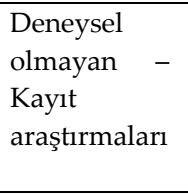 & $\begin{array}{l}\text { Evet - erken başlayan olarak } \\
\text { nitelendirilmeyen çocuklar ve } \\
\text { okula erken başlamayan fakat } \\
\text { öyle nitelendirilen çocuklar }\end{array}$ & Belirtilmemiş & $\begin{array}{l}\text { IQ }>132 \text { ve diğer gelişimsel değişkenler üzerindeki ortalama } \\
\text { performans üstünde olma (alg1, psikomotor, başarı ve } \\
\text { duygusallı). Sosyal- duygusal olgunluk okul psikoloğu } \\
\begin{array}{l}\text { tarafından resmi olmayan görüşme } \\
\text { değerlendirilmiştir. }\end{array} \\
\text { yoluyla }\end{array}$ \\
\hline
\end{tabular}


T. Ortaargun, F. Şahin / Karabük Üniversitesi Sosyal Bilimler Enstitüsü Dergisi, 2015, 5 (2), 300-322

\begin{tabular}{|c|c|c|c|c|c|}
\hline $\begin{array}{l}\text { N. M. Robinson ve } \\
\text { meslektaşları (1997) }\end{array}$ & $\mathrm{N}=276$ & $\begin{array}{l}\text { Tam } \\
\text { deneysel }\end{array}$ & $\begin{array}{l}\text { Evet - fakat üstün zekalı } \\
\text { olmayan çocuklar değil }\end{array}$ & Belirtilmemiş & $\begin{array}{l}\text { WPPSI-R, WISC-III veya K-ABC'nin aritmetik alttestlerin \%98 } \\
\text { veya üzerinde performans gösterenler }\end{array}$ \\
\hline $\begin{array}{l}\text { VanTessel-Baska ve } \\
\text { meslektaşları (1982) }\end{array}$ & $\mathrm{N}=14$ & $\begin{array}{l}\text { Karma } \\
\text { metot }\end{array}$ & Hayır & Belirtilmemiş & $\begin{array}{l}\text { WRAT'ın ya okuma ya da matematik alt testlerinde normun } \\
\text { 2-yaş üzerinde performansı olan çocuklar }\end{array}$ \\
\hline
\end{tabular}

Note: CMMS = Columbia Mental Maturity Scale; PPVT = Peabody Picture Vocabulary Test; KBIT = Kaufman Brief Intelligence Test; WISC-III = Wechsler Intelligence Scale for Children-Third Edition; K-ABC = Kaufman Assessment Battery for Children; WRAT = Wide Range Achievement Test. 
Her çalışma, McMillan ve Schumacher (2006) tarafından önerilen kategorileri kullanan araştırma tasarımına göre sınıflandırılmıştır. İçerdiği 11 çalışma arasından, 3'ü deneysel araştırma tasarımını kullandı (tam deneysel ya da yarı deneysel), 6'sı karma yöntemler yaklaşımını kullandı ve 2'si deneysel olmayan yaklaşımları kullanmıştır (Bakınız: Tablo 2).

Altı çalışma, kendi tasarımında bir kontrol grubu veya karşılaştırma grubu kullandığını bildirmiştir. N. M. Robinson meslektaşlarının (1997), benzer üstün zekâlı çocuklardan oluşan bir kontrol grubu kullanılmış; diğerlerinde ise, üstün zekalı çocukların performansı üstün zekalı olmayan çocukların performansıyla kıyaslandı (Castillo, 1998; Gagne \& Gagnie, 2004; Obrzut vd., 1984) ve ikisinde de hem üstün zekalı hem de üstün zekalı olmayan kontrol grupları kullanılmıştır (Karnes \& Johnson, 1987b; Meador, 1994).

\section{SONUÇLAR}

Çalışmaların kalitesini değerlendirme kriterleri, AERA (Amerika Eğitimsel Araştırma Kurumu) Yayınlarındaki Deneysel Sosyal Bilim Araştırmaları Raporlanması Hakkında Standartlar kadar Troia'nın (1999) çalışmasına da dayandırıldı. Değerlendirme için kullanılan kriterler dizisi Tablo 3'de verilmektedir. İçsel ve dişsal geçerlilikte iki genel kategori saptanmıştır. İç geçerlilik kategorisiyle birlikte, genel plan özelliklerinin konuları, ölçme, analiz ve yorumlama incelenmiştir. Dış geçerlilik kategorisi ise araştırma hipotezleri ve katılımcı seçimi ve tanımlama şeklinde bölünmüştür.

Tablo 4 ve 5'te, bu incelemedeki her bir çalışma özellik kriterlerine karşı değerlendirilmektedir. Belli bir araştırma planına uygun olmadığı varsayılan bir kriter olduğu durumlar n/a olarak kaydedilmiştir. Bir kriterin karşılanıp karşılanmadığını belirlemek için yayında yetersiz bilginin var olduğu durumlar olumsuz olarak değerlendirilmiştir. Bu incelemenin amacı bireysel çalışmaları eleştirmek değil, fakat üstün zekâlı eğitimi alanında başvurulan erken çocukluk dönemi araştırmalarının miktarı ve özellikleri hakkında tartışma zemini hazırlamaktır.

\section{İç Geçerlilik}

Genel plan özellikleri. Rastgele seçilmiş deneysel planlar, eğitim araştırmasının "altın standart" olarak düşünülmektedir ve konular arası farklılıkların giderilebildiği prosedürleri sunmaktadır (McMiilan \& Schumacher, 2006). İki çalışma, rastgele seçilen benzer biçimi kullandı̆̆ı ortaya çıkmıştır (Castillo, 1998; N.M. Robinson vd., 1997).

İyi planlanmış araştırma planlarının bir kontrol grubu içereceği genel olarak kabul edilmektedir (McMiilan \& Schumacher, 2006). İdeal olarak, müdahaleler, hem üstün zekâlı hem de üstün zekâlı olmayan kontrol gruplarıyla iki sebep için denenmelidir. İlk sebep, bir müdahalenin sadece tüm çocuklar için kullanımının uygun olduğu iyi bir öğretme tekniği olduğu olasılığını ortadan kaldırmaktadır. Karnes ve Johnson (1987b), Head Start programindaki potansiyel olarak üstün zekâlı çocuklara yönelik müdahalelerinin, üstün zekâlı olarak tanımlanmayan çocuklar için üst düzey düşünme becerileri (higher order thinking) kazanımlarıyla sonuçlandığını belirtmiştir. Aslında bu çocuklar müdahale grubundaki üstün zekalı çocuklarınkinden daha fazla 
kazanım tecrübe etmişler; bu sonuç ise uygulamanın üstün zekalı çocuklarda kullanımının gerçekten uygun olup olmadığı sorusunu akla getirmektedir. İkinci sebep, eğer tüm çocuklar için uygun olan stratejiler ve müfredat üstün zekâlı çocuklar için ayrılırsa, eğitimcilerin kendilerini elitizmin haklı suçlamalarına açık bırakmalarıdır (Borland, 1989; Carter, 1992; Passow, 1982).

Tablo 3. Çalışmaların Kalitesini Değerlendirme Kriteri

\begin{tabular}{|c|c|}
\hline Kriter & Açıklama \\
\hline \multicolumn{2}{|l|}{ İç Geçerlilik Kriteri } \\
\hline \multicolumn{2}{|l|}{ Genel Tasarm Özellikleri } \\
\hline Rastgele Seçme & Katılımcılar uygulanan müdahalelere rastgele seçilmiştir. \\
\hline Kontrol gruplu çalışma & Bir kontrol grubu kullanılmıştır. \\
\hline $\begin{array}{l}\text { Açıkça tanımlanmış } \\
\text { müdahale koşulları }\end{array}$ & $\begin{array}{l}\text { Müdahale koşulları, çalışmanın tekrar uygulanabilmesi için detaylı olarak } \\
\text { belirtilmiştir. }\end{array}$ \\
\hline $\begin{array}{l}\text { Belirtilen müdahale } \\
\text { uzunluğu }\end{array}$ & Müdahaleyi sürdürme zamanı belirtilmiştir. \\
\hline \multicolumn{2}{|l|}{ Ölçüm } \\
\hline Uygulanabilir ölçekler & $\begin{array}{l}\text { Bağımlı değişkenler çalışmanın gereklilikleri ve öneminin altında yatan } \\
\text { değişkenlere açıkça kanıt olması için yeterli detay verilmiştir. }\end{array}$ \\
\hline $\begin{array}{l}\text { Bağımlı değiş̧kenlerin } \\
\text { uygunluğu }\end{array}$ & Bağımlı değişkenler araştırma hipoteziyle ilgilidir. \\
\hline $\begin{array}{l}\text { Sunulan ölçeklerin } \\
\text { güvenilirliği }\end{array}$ & Bağımlı değişkenler için güvenilirliğin uygun ölçütleri mevcuttur. \\
\hline İşleyişin uygunluğu & $\begin{array}{l}\text { Müdahalenin güvenilir bir biçimde uygulandığını garantilemek için bir } \\
\text { prosedür yerine getirilmiştir. }\end{array}$ \\
\hline \multicolumn{2}{|l|}{ Analiz ve Yorumlama } \\
\hline Katılımcı sayısının yeterliliği & Katılımcıların sayısı seçilen araştırma planı için uygundur. \\
\hline Belirtilen analiz teknikleri & $\begin{array}{l}\text { Analitik teknikler verinin nasıl analiz edildiğini anlamaya imkan tanımak } \\
\text { için yeterli ölçüde ayrıntı verilmiştir. }\end{array}$ \\
\hline Uygun istatistiksel analiz & $\begin{array}{l}\text { Araştırma hipotezlerine uygun olan istatistiksel testler yapıldı ve uygun } \\
\text { şekilde rapor edilmiştir. }\end{array}$ \\
\hline Raporlanan etki boyutu & Etki boyutları belirtilmiştir. \\
\hline $\begin{array}{l}\text { Verilerin üçgenleme tekniği } \\
\text { ile kanıtlanması }\end{array}$ & Veriler üçgenlenmiştir. \\
\hline \multicolumn{2}{|l|}{ Diş Geçerlilik Kriteri } \\
\hline \multicolumn{2}{|l|}{ Araştırma hipotezleri } \\
\hline Problem oluşturma & Açık ve savunulabilir araştırma hipotezi kanıtlanmıştır. \\
\hline Bilgi birikimine katkısı & Araştırmanın rasyonelliğine göre açık bir durum sağlanmıştır. \\
\hline İlgili burs inceleme & İlgili burs incelemesi sağlanmıştır. \\
\hline $\begin{array}{l}\text { Araştırma tasarımını } \\
\text { tanımlama }\end{array}$ & $\begin{array}{l}\text { Çalışma tasarımının açık bir tanımı ve veri toplama metotlarını } \\
\text { içermektedir. }\end{array}$ \\
\hline \multicolumn{2}{|l|}{ Katılımo seçimi ve tanımlama } \\
\hline Katılımcı seçimi & Çalışma için hangi katılımcıların seçildiği usulü açıklanmıştır. \\
\hline Yaş & Her bir gruptaki katılımcıların ortalama kronolojik yaşı sunulmuştur. \\
\hline Cinsiyet & Her bir gruptaki bay ve bayan katılımcıların sayısı bildirilmiştir. \\
\hline Sosyo-ekonomik statü & Katılımcıların ailelerinin sosyo-ekonomik statüsü belirtilmiştir. \\
\hline Üstün zekalılığın tanımı & Katılımcılara uygulanan üstün zekalılık tanımı sunulmuştur. \\
\hline IQ & IQ ya da diğer standartlaştırılmış yetenek ölçümü bildirilmiştir. \\
\hline Çoklu kriter seçimi & $\begin{array}{l}\text { Öznel ve nesnel veri kullanarak, katılımcı seçiminde çoklu kriter yaklaşımı } \\
\text { kullanılmıştır. }\end{array}$ \\
\hline
\end{tabular}


Bir müdahalenin tekrarlanabilirliği, ayrıntısının yeterli şekilde tanımlanabilmesine bağlıdır. Çalışmaların 8'inde, tekrarlanabilirliği için yeterli tanım verilmiştir.

Ölçü. Tüm çalışmalarda sonuç çıktıları kullanılabilir hale getirildi, yani, görev değişkenleri ve ilgili temel değişkenlerin açık bir şekilde kanıtlanabilmesi için bağımlı değişkenler yeterli ayrıntıda tanımlanmıştır. Sadece üç çalışmada (Karnes vd., 1983a; 1983b; N.M. Robinson vd., 1997) bağımlı değişkenlerin güvenilirliği raporlanmıştır.

Uygulamanın uygunluğu tüm katılımcıların aynı müdahaleyi aldığını garantilemişlerdir. Bu olmadan, bağımlı değişkinler üzerindeki etkinin müdahale tarafından sağlandığının, müdahaleyi yapan öğretmendeki farklılık gibi bazı konu dışı faktör tarafından sağlanmadığının kesinliği belirsizdir. Sadece iki çalışma uygulamanın uygunluğunun herhangi bir ölçümü olduğunu göstermiştir (Castillo, 1998; Meador, 1994) ve her iki örnekte de müdahale aynı kişi tarafından uygulanmıştır. Daha geniş bir çalışma, kılavuzların ve personel eğitimini kullandığını göstermesine rağmen hiçbir çalışmada, uygulamanın uygunluğu konusu açıkça belirtilmemiştir (N.M. Robinson vd., 1997). 
T. Ortaargun, F. Şahin / Karabük Üniversitesi Sosyal Bilimler Enstitüsü Dergisi, 2015, 5 (2), 300-322

\begin{tabular}{|c|c|c|c|c|c|c|c|c|c|}
\hline Çalışma & $\begin{array}{l}\text { Rastgele } \\
\text { Seçim }\end{array}$ & $\begin{array}{l}\text { Mevcut } \\
\text { Kontrol } \\
\text { Grubu }\end{array}$ & $\begin{array}{l}\text { Açıkça } \\
\text { Müdahale I }\end{array}$ & $\begin{array}{l}\text { tanımlanmış } \\
\text { Koşulları }\end{array}$ & $\begin{array}{l}\text { Belirtilen } \\
\text { Müdahalenin } \\
\text { Süresi }\end{array}$ & & $\begin{array}{l}\text { Uygulanabilir } \\
\text { Ölçümler }\end{array}$ & $\begin{array}{l}\text { Bağımlı Değişkenin } \\
\text { Uygunluğu }\end{array}$ & $\begin{array}{l}\begin{array}{l}\text { Sunulan ölçülerin } \\
\text { güvenilirliği }\end{array} \\
\text { a }\end{array}$ \\
\hline Castillo (1998) & $\bar{E}$ & $\bar{E}$ & & $\bar{E}$ & $\bar{E}$ & & $\bar{E}$ & E & $\mathrm{H}$ \\
\hline Gagné ve Gagnier (2004) & $\mathrm{H}$ & $\mathrm{H}$ & & $\mathrm{H}$ & E & & E & E & $\mathrm{H}$ \\
\hline Hanninen (1984) & $\mathrm{H}$ & $\mathrm{H}$ & & $\mathrm{E}$ & E & & E & E & $\mathrm{H}$ \\
\hline Karnes ve Johnson (1987b) & $\mathrm{H}$ & E & & E & E & & E & E & $\mathrm{H}$ \\
\hline Karnes ve Johnson (1987a) & $\mathrm{H}$ & $\mathrm{H}$ & & E & E & & E & E & $\mathrm{E}$ \\
\hline Karnes ve meslektaşları (1983a) & $\mathrm{H}$ & $\mathrm{H}$ & & $\mathrm{H}$ & E & & E & E & $\mathrm{H}$ \\
\hline Karnes ve meslektaşları (1983b) & $\mathrm{H}$ & E & & $\mathrm{H}$ & E & & E & E & E \\
\hline Meador (1994) & E & E & & E & E & & E & E & $\mathrm{H}$ \\
\hline Obrzut ve meslektaşları (1984) & $\mathrm{H}$ & E & & E & E & & E & E & $\mathrm{H}$ \\
\hline $\begin{array}{l}\text { N. M. Robinson ve meslektaşları } \\
\text { (1997) }\end{array}$ & E & E & & E & E & & E & E & E \\
\hline $\begin{array}{l}\text { VanTassel-Baska ve meslektaşları } \\
\text { (1982) }\end{array}$ & $\mathrm{H}$ & $\mathrm{H}$ & & E & E & & E & E & $\mathrm{H}$ \\
\hline \multicolumn{10}{|l|}{ Not:E=Evet, H=Hayır } \\
\hline \multicolumn{10}{|l|}{ Tablo 4. (Devam) } \\
\hline Çalışma & $\begin{array}{l}\text { İşleyiş } \\
\text { Uygunluğu }\end{array}$ & $\begin{array}{l}\text { Yeterli s } \\
\text { (N) }\end{array}$ & 1da katılımc1 & $\begin{array}{l}\text { Tanimlana } \\
\text { teknikleri }\end{array}$ & analiz & $\begin{array}{l}\text { Yeterli } \\
\text { analiz }\end{array}$ & istatistiksel & Belirtilen etki boyutu & Veri nirengi kanıtı \\
\hline Castillo (1998) & $\mathrm{E}$ & & E & & $\mathrm{E}$ & & $\bar{E}$ & $\mathrm{H}$ & $\mathrm{n} / \mathrm{a}$ \\
\hline Gagné ve Gagnier (2004) & $\mathrm{H}$ & & E & & E & & E & $\mathrm{H}$ & $\mathrm{E}$ \\
\hline Hanninen (1984) & $\mathrm{n} / \mathrm{a}$ & & E & & E & & E & $\mathrm{H}$ & $\mathrm{H}$ \\
\hline Karnes ve Johnson (1987b) & $\mathrm{H}$ & & E & & E & & E & $\mathrm{H}$ & $\mathrm{E}$ \\
\hline Karnes ve Johnson (1987a) & $\mathrm{H}$ & & $\mathrm{H}$ & & E & & E & $\mathrm{H}$ & E \\
\hline Karnes ve meslektaşları (1983a) & $\mathrm{n} / \mathrm{a}$ & & $\mathrm{H}$ & & E & & E & $\mathrm{H}$ & E \\
\hline Karnes ve meslektaşları (1983b) & $\mathrm{n} / \mathrm{a}$ & & $\mathrm{H}$ & & E & & E & $\mathrm{H}$ & E \\
\hline Meador (1994) & $\mathrm{E}$ & & E & & E & & E & $\mathrm{H}$ & E \\
\hline Obrzut ve meslektaşları (1984) & $\mathrm{H}$ & & E & & $\mathrm{E}$ & & $\mathrm{E}$ & $\mathrm{H}$ & E \\
\hline $\begin{array}{l}\text { N. M. Robinson ve meslektaşları } \\
\text { (1997) }\end{array}$ & $\mathrm{H}$ & & E & & $\mathrm{E}$ & & E & $\mathrm{H}$ & $\mathrm{H}$ \\
\hline $\begin{array}{l}\text { VanTassel-Baska ve meslektaşları } \\
\text { (1982) }\end{array}$ & $\mathrm{H}$ & & $\mathrm{H}$ & & E & & E & $\mathrm{H}$ & E \\
\hline
\end{tabular}


Tablo 5. Dış Geçerlilik Kriteriyle Çapraz Referanslı Çalışmalar

\begin{tabular}{|c|c|c|c|c|c|c|c|c|c|c|c|}
\hline Çalışma & $\begin{array}{l}\text { Problem } \\
\text { oluşturma }\end{array}$ & $\begin{array}{l}\text { Bilgi } \\
\text { birikimine } \\
\text { katk1sı }\end{array}$ & $\begin{array}{l}\text { Ilgili } \\
\text { burs } \\
\text { inceleme }\end{array}$ & $\begin{array}{l}\text { Plan } \\
\text { tanımlaması }\end{array}$ & $\begin{array}{l}\text { Katılımcı } \\
\text { seçimi }\end{array}$ & Yaş & Cinsiyet & SES & $\begin{array}{l}\text { Üstün } \\
\text { zekalılık } \\
\text { tanımları } \\
\end{array}$ & IQ & $\begin{array}{l}\text { Çoklu } \\
\text { kriter } \\
\text { seçimi }\end{array}$ \\
\hline Castillo (1998) & $\mathrm{E}$ & $E$ & $\mathrm{E}$ & $E$ & $\mathrm{H}$ & $E$ & $E$ & $E$ & $\mathrm{H}$ & $\mathrm{H}$ & $\overline{\mathrm{H}}$ \\
\hline $\begin{array}{l}\text { Gagné ve Gagnier } \\
\text { (2004) }\end{array}$ & $\mathrm{E}$ & $\mathrm{E}$ & $\mathrm{E}$ & $\mathrm{E}$ & $\mathrm{E}$ & $\mathrm{E}$ & $\mathrm{E}$ & $\mathrm{H}$ & $\mathrm{H}$ & $\mathrm{E}$ & $\mathrm{E}$ \\
\hline Hanninen (1984) & $\mathrm{E}$ & $\mathrm{E}$ & $\mathrm{E}$ & $\mathrm{E}$ & $\mathrm{E}$ & $\mathrm{H}$ & $\mathrm{H}$ & $\mathrm{H}$ & $\mathrm{E}$ & $\mathrm{H}$ & $\mathrm{E}$ \\
\hline $\begin{array}{l}\text { Karnes ve Johnson } \\
(1987 b)\end{array}$ & $\mathrm{E}$ & $\mathrm{E}$ & $\mathrm{E}$ & $\mathrm{E}$ & $\mathrm{E}$ & $\mathrm{H}$ & $\mathrm{H}$ & $\mathrm{E}$ & $\mathrm{E}$ & $\mathrm{H}$ & $\mathrm{E}$ \\
\hline $\begin{array}{l}\text { Karnes ve Johnson } \\
\text { (1987a) }\end{array}$ & $\mathrm{E}$ & $\mathrm{E}$ & $\mathrm{E}$ & $\mathrm{E}$ & $\mathrm{E}$ & $\mathrm{H}$ & $\mathrm{H}$ & $\mathrm{E}$ & $\mathrm{E}$ & $\mathrm{E}$ & $\mathrm{E}$ \\
\hline $\begin{array}{l}\text { Karnes ve } \\
\text { meslektaşları(1983a) }\end{array}$ & $\mathrm{E}$ & $\mathrm{E}$ & $\mathrm{H}$ & $\mathrm{E}$ & $\mathrm{E}$ & $\mathrm{H}$ & $\mathrm{H}$ & $\mathrm{H}$ & $\mathrm{E}$ & $\mathrm{E}$ & $\mathrm{E}$ \\
\hline $\begin{array}{l}\text { Karnes ve } \\
\text { meslektaşları(1983b) }\end{array}$ & $\mathrm{E}$ & $\mathrm{H}$ & $\mathrm{H}$ & $\mathrm{E}$ & $\mathrm{E}$ & $\mathrm{E}$ & $\mathrm{E}$ & $\mathrm{H}$ & $\mathrm{H}$ & $\mathrm{H}$ & $\mathrm{E}$ \\
\hline Meador (1994) & $\mathrm{E}$ & E & $\mathrm{E}$ & E & $\mathrm{E}$ & E & $\mathrm{H}$ & $\mathrm{H}$ & $\mathrm{H}$ & $\mathrm{E}$ & $\mathrm{E}$ \\
\hline $\begin{array}{l}\text { Obrzut ve } \\
\text { meslektaşları(1984) }\end{array}$ & $\mathrm{E}$ & $\mathrm{E}$ & $\mathrm{E}$ & $\mathrm{E}$ & $\mathrm{E}$ & $\mathrm{E}$ & $Y$ & $\mathrm{H}$ & $\mathrm{H}$ & $\mathrm{E}$ & $\mathrm{E}$ \\
\hline $\begin{array}{l}\text { N. M. Robinson ve } \\
\text { meslektaşları(1997) }\end{array}$ & $\mathrm{E}$ & $\mathrm{E}$ & $\mathrm{E}$ & $\mathrm{E}$ & $\mathrm{E}$ & $\mathrm{E}$ & $\mathrm{E}$ & $\mathrm{E}$ & $\mathrm{H}$ & $\mathrm{E}$ & $\mathrm{H}$ \\
\hline $\begin{array}{l}\text { VanTassel-Baska ve } \\
\text { meslektaşları(1982) }\end{array}$ & $\mathrm{E}$ & $\mathrm{E}$ & $\mathrm{E}$ & $\mathrm{E}$ & $\mathrm{E}$ & $\mathrm{E}$ & $\mathrm{E}$ & $\mathrm{H}$ & $\mathrm{H}$ & $\mathrm{E}$ & $\mathrm{E}$ \\
\hline
\end{tabular}


Analiz ve yorumlama. Birçok çalışmada, katılımcıların sayısı azdır. Sonuçların pratik öneminin onun hesaplanmasına dayandırıldığı geniş ölçüde kabul edilmesine rağmen, hiçbir çalışma etkinin boyutunu sunmamıştır (McMiilan \& Schumacher, 2006). Tüm çalışmalar, çoklu veri kaynaklarını kullanarak veri nirengisinin kanıtını göstermiştir.

\section{Diş Geçerlilik}

Araştırma hipotezleri. Bütün çalışmalar açık ve savunulabilir araştırma hipotezi içermektedir ve biri hariç hepsi (Karnes vd., 1983b) araştırmalarının alan bilgisine yapılan katkısını belirtmiştir. İki çalışma alanla ilgili öğrenimi incelemeyi kapsamamaktadır (Karnes vd., 1983a; 1983b). Bu eksiklik, bu makalelerin ayn çalışmanın farklı yönlerini sunduğu ve literatür incelemesini daha önceki bir makalenin içerdiği gerçeğine katkıda bulunabilir. Tüm çalışmalar kullanılan planın ve verilerin hangi yolla toplandığı açıklamasına sahiptir.

Katılımo seçimi ve tanımlama. Çalışmalardan birisinde (Castillo, 1998), katılımcıların nasıl seçildiğiyle ilgili yeterli bir bilgi içermemekteydi. Bu özel durumda, çocukların onların üstün zekalı çocuklar için hizmet veren bir programda yer aldığı için üstün zekalı olduğu varsayılmıştır. Fakat, söz konusu programa çocukların nasıl seçildiğiyle ilgili herhangi bir detay bilgi verilmemiştir.

Çalışmaların pek çoğu, katılımcıların ortalama yaş veya cinsiyet dağılımı gibi temel bilgileri içermemektedir. Çalışmaların sadece 4'ünde, öğrencilerin seçimi ve müdahaleye dayandırılan üstün zekâlılık tanımı bildirilmiştir. Çalışmaların toplamında, 7'sinde çalışmaya seçilen çocukların IQ'ları yer almıştır. 11 çalışmanın 9'unda çoklu kriter kullanılmıştır.

\section{TARTIŞMA}

Metodolojik olarak ve incelenen özellikler boyutu ile çeşitlilik gösteren az sayıda çalışma, üstün zekâlı eğitimi alanında erken çocukluk dönemi araştırmacılarının, doğru kanıtlara dayandırılmış uygulamaların var olduğu iddia edilmeden önce hala yapacakları çok işi olduğuna işaret etmektedir. Hiç kuşkusuz, üstün zekâlı eğitiminde deneysel araştırma yapılmasında çok fazla zorluk söz konusudur. Bu durum ise kalitede düşme ve araştırma çeşitliliğinde yetersizliğine sebep olabilir. Bu zorluklar örneklem büyüklüğü, örneklem seçimiyle ilgili problemler, üstün zekâlılık tanımları, üstün zekalı çocuklarda kullanılacak uygun bağımlı değişkenleri bulma ve seçme, genç üstün zekalı çocukların program çıktıları farklılığının ölçümü biçiminde sıralanabilir.

\section{Örneklem}

Hedef kitlenin büyüklüğü (Örn., erken çocukluk dönemindeki üstün zekalı çocuklar), tanım gereği, kitlenin en üst \%10'undan (Gagne, 2003) en üst \% 2'sine (Terman, 1925) daha gelenekçi tahminlere uzanmakla birlikte, düşüktür (Ziegler \& Raul, 2000). Bu, yeterli dış geçerlilik sağlayacak örnek boyutlarının bulunmasının, özellikle belli bir yaş aralığını gruba seçerken güçlükle karşılaşılacağı anlamına gelmektedir. Ayrıca, uygun çocukları bulmak var olan bakım hizmetleri çeşitliliği 
yüzünden okul öncesi dönemlerde daha zordur; örneğin, çocuklar bir gün ebeveynleri tarafından, diğer gün büyükanne tarafından bakılıyor olabilir ve haftanın diğer üç günü kreş ya da günlük bakıma gidiyor olabilir (N.M. Robinson vd., 2008). Bu sorun, çok küçük çocuklarla yapılan araştırmalarda daha da kötüleşmektedir, çünkü hem aileler hem de eğitimciler çocukları korumak için güdüsel davranışlara sahiptir. Okul öncesi gruplarlarla alakalı çalışmaların çoğu, çok az örneklerle sürdürülmüştür. Yani, 30'dan daha az sayıda katılımcı içermektedir. Bu kuralın tek istisnası, devam eden bir programın (Umut Veren Engelli ve Yetenekli Gençleri Geri Kazanımı ve Hızlandırılması [RAPYHT]) genişletilebilir ve Head Start Programinda olan katılımcıları seçerek tekrarlanabilir olduğu Karnes ve Johnson (1987b) tarafından gerçekleştirilmiştir. Sorulması gereken soru, genç üstün zekâlı çocuklarda başarılı olduğu görülen okul öncesi programlar niçin tekrarlanmadığı ve daha geniş örneklemlerle niçin çalışılmadı̆̆ıdır.

\section{Kontrol ve Karşılaştırma Gruplanı}

Bir kontrol grubu ve/ veya bir karşılaştırma grubunun iyi bir deneysel plan için önemli olduğu kabul edilmesine rağmen bu incelemeyi içeren birkaç çalışmada bir kontrol grubu kullandığı bildirilmiştir. Yeniden incelenmiş çalışmalardan bazıları diğer metotları kullanan değişkenleri kontrol etmek için girişimlerde bulunmuştur. Karnes ve Johnson (1987a), uygun bir karşılaştırma grubu bulamadığından, çocukların seviye başarı testlerini onların eğitsel yetenekleri oranı üzerine dayandığı beklenen puanlarla kıyaslamıştır. Bu yöntemde yapılan müdahaleye bir katkı sağlayıp sağlayamayacağı geçerli bir kontrol grubu olmadan belirlenmesine rağmen, öğrencilerin sadece \%3'ü beklenenin altında performans göstermiştir.

Karnes ve meslektaşları (1983b), her bir grubun performans değerlendirmesini belirlemek için giriş ölçütleri ve son test sonuçlar arasındaki korelâsyonu kullanarak bir müdahalenin etkililiğinin değerlendirildiği regresyon-devamsızlık analizi (regression - discontinuity analysis) kullanmıştır (s.106). Onlar aynı sınıfa kaydolmuş fakat programda edinilen kazanımların eğitsel olarak önemli ya da sadece olgunlaşma, düzenli eğitsel program ya da test sürecine bağlı olup olmadığını belirlemek için RAPYHT'i değerlendirmediği çocuklardan oluşan bir karşılaştırma grubu kullanmışlardı. Küçük bir örnek boyutlarıyla bile, müdahalede bulunulan çocukların kendi yetenek alanlarıyla ilgili testlerde, yaratıcı işleyiş ve okulla ilgili başarı motivasyonu üzerinde çalışmada yer almayan çocuklardan daha iyi performans gösterdiklerini saptamışlardır.

\section{Tesadüfî Örnekleme}

Üstün zekâlı çocuklar araştırmasında uygulama ve kontrol gruplarındaki öğrencilerin tesadüfi (random) seçimini dikkate alan etik konular vardır. Programın etkili olup olmadığını saptamak için örneğin, potansiyel olarak faydalı olan bir müdahaleyi bir çocuktan esirgemek eğitimsel sorumluluk mudur (Borland, 1989; Carter, 1992; Kitano \& Perz, 1998)? Araştırmanın, kontrol grubuna sonradan uygulanan müdahaleye izin vermesini planladığını ya da müdahalede bulunulmayan grupların bu ikilemi önlemek için bir yol sağlaması öne sürülmektedir. Bu her zaman 
mümkün değildir, ayrıca, çalışmanın maliyetini ve süresi artmaktadır. Burada incelenen çalışmaların hiç birisinde, deneysel aşamadan sonra kontrol grubuna benzer müdahale sunulmamıştır.

\section{Üstün Zekâlılığın Tanımları}

İncelemenin şaşırtıcı bir yönü, üstün zekâlılığının amaçlanan anlamını açıklayamayan bir sürü çalışmanın olmasıydı. Sadece iki çalışma üstün zekâlılığın resmen bilinen tanımına değindi, belki de zorluk uygulayıcılarına yansıyan, erken çocukluk ortamında resmi tanımlamalarla ilgili uygulamaya sahip olmasıdır. Üstün zekâlılığın tanımlarında ağır basan ve bunlarla ilgili hararetli bir tartışma üstün zekâlı çocuklara yapılan müdahale çalışmalarını kıyaslamaktadır (Carter, 1991; Ziegler \& Raul, 2000). Örneğin, bir çalışmada kullanılan modelde tanımlanan üstün zekâlılık tanımı yüksek başarı iken bir diğerinde yetenek puanları olabilmektedir. Bundan dolayı, toplanan veriler farklılaşabilmekte ve karşılaştırma yapmada problemler ortaya çıabilmektedir.

\section{Çoklu Kriter Tanımlama}

Çalışmaların daha güçlü göründüğü bir alan, üstün zekalı katılımcıları seçmek için bir dizi ölçütleri kullanan çoğu çalışmalarla birlikte, çok boyutlu tanımlama yöntemlerinin gerekli olduğu bir onay sürecidir (Robinson vd., 2007). İlginçtir ki, VanTessel-Baska ve meslektaşları (1982) katılımcıları aday göstermek için çok ölçütlü bir yaklaşım kullandığını fakat tüm aileler çocuklarının yüksek seviyede faal oldukların belirtmekle beraber, ailelerin bilgisinin yetenekli olanları belirlemede iyi bir veri kaynağı olmadığını ortaya koymuştur. VanTessel-Baska ve meslektaşları, ileri düzeye akademik programdaki potansiyel başarının ölçümüne ilişkin test sonuçlarının, ailelerden elde edilen verilerden daha iyi olduğu sonucuna varmıştır. Bu belki de, çalışma test sonuçlarının kullanımıyla ölçüldüğü için şaşırtıcı olmayan bir sonuçtur.

\section{Bağımlı Değişken Ölçüleri}

Bağımlı değişken ölçülerinin geniş bir dizisi çalışmalara karşı kullanılmıştır. Kitano ve Perez (1998) erken çocukluk dönemindeki çocuklarla yapılan araştırmanın özellikle ilgili çekici olduğu çünkü araştırmacıların sonraki eğitsel müdahalelerdeki genç çocuklarda zihinsel kazanımları ölçmek için uygun materyalleri bulmada zorluklarla karşılaştıklarını belirtmiştir. Bazı koşullarda, bir araç genç çocuklarda norm grubu olan bir örneğe sahip olmayabilir böylece normal toplulukla bir karşılaştırma yapılamama problemini ortaya çıkarabilir. Ayrıca, genç üstün zekâlı çocuğun ileri düzey yeteneği, yaşına uygun materyaller kullandığında tavan etkisiyle karşılaşılacağı anlamına da gelebilir (Borland, 1989; Carter, 1991). Örneğin bir programa \% 99'la kaydolmuş ve programdan aynı seviyede ayrılmış bir çocuk yıl boyunca hiçbir şey kazanmamış mıdır ya da uygulama sonrası verileri onun en üst sınırdaki ölçümünü mü yansıtır? Dahası, bir programın ya da müdahalenin başarılı olup olmadığını belirlemek için kazanım miktarının ne kadar olması gerektiği gibi tespit edilmiş bir kriter yoktur. Etki boyutunun ölçümü, istatistiksel önemiyle beraber, 
bu problemi azaltmaya yardım edebilir. Ayrıca burada sunulan müdahalelerin hiç birisi herhangi bir etki boyutu ölçümü içermemektedir.

VanTessel-Baska ve meslektaşları (1982), “Program öğrencileri kelime hâkimiyetini PPVT ölçümü öncesi ve sonrası \%10 oranında arttıracaktır" gibi sonuçları içeren programların ölçülebilir hedefler koyduklarını bildirmişlerdir (s.47). Bazı bireysel sonuçların sıradışı olduğuna değinilmesine rağmen, çalışmalarda bireysel sonuçlar ya da kazanımlar değil grubun ortalama puanları bildirilmektedir. Böyle küçük ve olağandışı özel örnekle tek bir konu tasarımı, bu alandaki deneysel araştırma için daha ileri bir seçenek sunabilir.

Bazı araştırmacılar (Mathews \& Burns, 1992; Morgan, 2007) programın etkililiğinin sayısal ölçümlerini kullanmanın oldukça zor olduğunu ve aile, öğretmen ve öğrenci anketleri ile görüşmeler gibi nitel ölçümlerin programı değerlendirme için zengin bir veri sağladığını belirtmişler. Hertzog ve meslektaşları (1999) öğrenmeyi gerçekleştirirken ya da düşünme süreçlerindeki ilerlemeyi belgelemenin zor olduğunu belirtmiştir (s.44). Geleneksel test öncesi ya da sonrası ölçümler olmadan öğretmenler, çocukların müdahale öncesi ve sonrasındaki deneyimlerini belgeleyerek öğrenci gelişimini rapor edebileceği sonucuna varmışlardır.

Katılımcılar ve ailelerin algıları programın başarısında ve verimliliğinde önemli bir faktördür, müfredat kararları sadece bilgi ve becerilerdeki gerçek kazanımları ölçme girişimi olmadan hissedilen yararlar üzerine dayandırılmamalıdır. Bunu yapmak mümkün olduğunda, neyin ölçüleceği fikri belirlenmelidir. Müdahalelerin verimliliğini ölçen bir araştırmaya başvurmak bu müdahalelerin açıkça belirtilmiş hedeflerini ve sonuçlarını gerektirmektedir. Üstün zekalı çocuklarla hedefler ve sonuçların tanımlanması zor olabilmektedir. Eğitimciler kendi güç alanlarında önceden hakim oldukları ve akranları için uygun müfredat kazanımları ötesine gitme ihtimali olan çocukları teşvik etmek ve yaymak için çalışmaktadırlar. Kitono ve Perez (1998) genç üstün zekalı çocuklar için uygun olan hedeflerin çoğunlukla uzun dönemli, bireysel ve entelektüel risk alma gelişimi veya ileriki yetersiz başarının önlenmesi gibi işlevsel olarak tanımlanmasının zor olduğunu söylemişlerdir. Bu alanlardaki başarı ve kazanımların ölçümü ve böyle bir süreç araştırmacılar için zorlayıcı olmaktadır.

Karnes ve Johnson (1987a) okulöncesi dönemdeki üstün zekalılar için bilişsel hedefler yerine uygun hedefleri kapsamasını önerdi:

(a) Sağlıklı bir benlik ve özsaygı,

(b) Uygun kişilerarası beceriler,

(c) Öğrenme için yüksek seviyede merak ve motivasyon,

(d) Çalışmayı sürdürme yeteneği,

(e) Risk almaya istekli olma,

(f) Yaratıcı ve üretken düşünmeyle meşgul olma yeteneği, 
(g) Daha yüksek seviyede düşünme süreçleri edinimi,

(h) Bağımsız ve grupla çalışma yeteneği.

\section{Gelecekteki Araştırmalara Etkileri}

Genç üstün zekalı çocuklara müdahalelerin verimli olarak yapılması belli müdahalenin arkasındaki teoriyi anlayan eğitimciler gerektirmektedir. Üstün zekalı eğitimi alanındaki araştırma ve eğitimcilerin gün gün uygulaması arasındaki mevcut fark, Wadlington ve Burns (1993) tarafından gerçekleştirilen bir araştırmasında incelenmiştir. Eğitimciler, genellikle genç çocukların düzeyine ağır olduğu farz edilen ileri düzey materyal ve kavramların üstün zekalılar için geçerli olduğunu kabul etmeleri rağmen, ne kullanılan materyaller ne de araştırmacıların belirttiği öğretim kavramlarında zaman ve ölçme gibi matematiksel düzeydeki kavramlar genç öğrencilere yönelikti. Olağan erken çocukluk döneminde benimsenen müdahalelerin kolaylığı genç üstün zekalı çocuklar için yeni müdahaleleri geliştiren ve deneyen araştırmacılara önemli bir ilgi odağı olmalıdır.

Karnes ve Johnson (1987a) üstün zekalı çocuklar için kavramsal modelinin önceki incelemesinin ve Illinois Üniversitesindeki genç üstün zekalı çocuklar program değerlendirmesaklaşımdaki farklılıklara rağmen, her programın kapsadığı çocuklar için ölçülebilir hedefler gösterdiğini ortaya çıkarmıştır. Karnes ve Johnson (1987a) yaklaşımdaki farklılıkların üstün zekalı çocukların ihtiyaçlarını sağlamak için tek bir tane iyi yol olmadığı görüşünü desteklediği sonucuna varmışlardır. Ayrıca çocukların uygun çoklu kriter tanımlamasının önemi, ailenin ilgisi, devam eden değerlendirme, programlamayı değerlendirmeye bağlama, daha yüksek seviyede düşünmeyi destekleyen ve güçlü yönleri üzerine dayanan programlama ve farklı düşünme üzerindeki önem gibi birçok genel faktörleri sunmuşlardır.

Bir çok tanınmış ve sıklıkla atıfta bulunulan incelemelere ve genç üstün zekalı çocuklarda kullanımı desteklenen meta analize rağmen (Kulik \& Kulik, 1984; Proctor, Black \& Feldhusen, 1986; Rogers, 1992), şaşırtıcı olarak ilkokula erken başlamayla ilgili sadece iki çalışma belirlenmiştir (Gagne \& Gagnier, 2004; Obrzut vd., 1984). Erken kayıtın verimliliği hakkında bildiğimiz şeylerin çoğu 1950'lerde ve 1960'larda yapılan çalışmalara dayanmaktadır. Önceki yıllarda eğitimsel stratejiler ve pedagojideki önem verilen değişiklikler Rogers'in 1966-1988 sürecinde tamamının reddedildiği görülen ilerlemenin etki boyutunu bulmasıyla birleştirilmiştir, bu daha sonraki araştırmalar için hazır bir alan olmuştur.

Ayrıca, tek bir istisna dışında (Obrzut vd., 1984) bu makalede sunulan çalışmalar erken çocuklar dönemi temel eğitimi veya özel eğitim dergileri yerine üstün zekalı eğitimi dergilerinde ortaya çıkmaktadır. Erken çocukluk dönemi üstün zekalı eğitimi alanında çalışanların belkide deneyimleri daha çok kullanmaya ve erken çocukluktaki düzenlemelerde genç çocuklarla çalışan meslektaşların metotları ve diğer özel ihtiyaçlarla beraber genç çocukları araştırmaya ihtiyaçları vardır. Öyle olmazsa, White ve meslektaşlarının (2003) belirttiği gibi bu alanda etkili olanların belli fikirleri tarafından sınırlandırılmış kalıntıları uygulayan ve kendi kendini yenileyen 
ve diğer seçeneklerin göz önüne alınmadığı tehlikeleri risk edinmektedir (p. vii). Örneğin belli topluluklarla ve engelliler araştırma tasarımlarının popülerliğine rağmen, bu incelemeyi içeren tek desenli bir çalışma planı yoktur. Üstün zekalı eğitimi yayınlarının bir sonraki araştırması sadece, yayınlanmış tek desenli bir çalışma planı ortaya çıkarmıştır (Simonsen, Little \& Fairbanks, 2010). Swassing ve Amidon (1991), Foster (1986) ve son zamanlarda Simonsen ve Little (2001), bu planın üstün zekalı eğitimindeki araştırma için özel çekiciliği olduğunu belirtmişlerdir.

\section{SONUÇ}

Erken çocukluk döneminde üstün zekalı eğitiminde kanıta dayalı uygulama belirlemenin ilgi çekici bir girişim olduğu açıktır. Bu alanda yazılan şeylerin çoğu iyi niyetli düşüncelere, daha büyük çocuklar üzerinde yürütülen araştırmalardan erken çocukluk uygulaması sonucuna ulaşma girişimlerine ya da yetersiz tasarlanmış çalışmalara dayanmaktadır. Genç çocuklar için üstün zekalı programların en büyük eksikliklerinden birisinin iyi yapılandırılmış ve ölçülebilir hedeflerin eksik olduğu açıkça görülmektedir. Geçmiş araştırmalar, genç üstün zekalı çocuklar için en etkili program türlerini neyin oluşturabileceği gibi bir çok öneri sağlamaktadır. Şu an ki sorun bu önerileri ciddi olarak değerlendirmektedir. Genç üstün zekalı çocuklar için en iyi sonuçları sağlayan program ve müdahale türlerini inceleyen titiz araştırmalara ihtiyaç duyulmaktadır. Programın felsefesi, üstün zekalılık kavramı, hedef toplum ve çevresel faktörler bu sonuçların tüm doğasını tamamen etkileyecektir.

\section{Çelişkili İlgi Alanları Bildirimi}

Yazarlar, araştırma, kaynak ve/veya bu makalenin basımı hakkında hiç potansiyel çelişkili ilgi alanları olmadığını bildirmiştir.

\section{KAYNAKÇA}

Adkins, D., \& Ballif, B. (1973). Animal crackers: A test of motivation to achieve. Monterey, CA: McGraw-Hill.

American Educational Research Association. (2006). Standards for reporting on empirical social science research in AERA publications. Educational Researcher, 35, 33-40.

Barbour, N., Shaklee, B. D. (1998). Gifted education meets Reggio Emilia: Visions for curriculum in gifted education for young children. Gifted Child Quarterly, 42, 228-237.

Borland, J. H. (1989). Planning and implementing programs for the gifted. New York, NY: Teachers College Press.

Carter, K. R. (1991). Evaluation of gifted programs. In N. K. Buchanan \& J. F. Feldhusen (Eds.), Conducting research and evaluation in gifted education (pp. 245-274). New York, NY: Teachers College Press.

Carter, K. R. (1992). A model for evaluating programs for the gifted under non-experimental conditions. Journal for the Education of the Gifted, 15, 266-283.

Castillo, L. C. (1998). The effect of analogy instruction on young children's metaphor comprehension. Roeper Review, 21, 27-31. 
Chamberlin, S. A., Buchanan, M., Vercimak, D. (2007). Serving twice-exceptional preschoolers: Blending gifted education and early childhood special education practices in assessment and program planning. Journal for the Education of the Gifted, 30, 372-393.

Coates, D., Thompson, W., Shimmin, A. (2008). Using learning journeys to develop a challenging curriculum for gifted children in a nursery (kindergarten) setting. Gifted and Talented International, 23, 97-104.

Diezmann, C. M., English, L. D. (2001). Developing young children's multidigit number sense. Roeper Review, 24, 11-13.

Diezmann, C. M., Watters, J. J. (1997). Bright but bored: Optimising the environment for gifted children. Australian Journal of Early Childhood, 22(2), 17-21.

Foster, W. (1986). The application of single subject research methods to the study of exceptional ability and extraordinary achievement. Gifted Child Quarterly, 30, 33-37.

Gagné, F. Y. (2003). Transforming gifts into talents: The DMGT as a developmental theory. In N. Colangelo and G. A. Davis (Eds.), Handbook of gifted education (3rd ed., pp. 60-74). Boston, MA: Allyn \& Bacon.

Gagné, F. Y., Gagnier, N. (2004). The socio-affective and academic impact of early entrance to school. Roeper Review, 26, 128-138.

Hanninen, G. E. (1984). Effectiveness of a preschool program for the gifted and talented. Journal for the Education of the Gifted, 7, 192-204.

Hensel, N. H. (1991). Social leadership skills in young children. Roeper Review, 14, 4-6.

Hertzog, N. B., Klein, M. M., Katz, L. G. (1999). Hypothesizing and theorizing: Challenge in an early childhood curriculum. Gifted and Talented International, 14, 38-49.

Johnsen, S. K., Ryser, G. R. (1996). An overview of effective practices with gifted students in general-education settings. Journal for the Education of the Gifted, 19, 379-404.

Jolly, J. L., Kettler, T. (2008). Gifted education research 1994-2003: A disconnect between priorities and practice. Journal for the Education of the Gifted, 31, 427-446.

Karnes, M. B., Brown, J. G., Shwedel, A. M., Svoboda, M. H. (1980). RAPYHT project talent assessment checklist. Urbana: University of Illinois.

Karnes, M. B., Johnson, L. J. (1987a). An imperative: Programming for the young gifted/ talented. Journal for the Education of the Gifted, 10, 195-214.

Karnes, M. B., Johnson, L. J. (1987b). Bringing out Head Start talents: Findings from the field. Gifted Child Quarterly, 31, 174-179.

Karnes, M. B., Shwedel, A. M., Lewis, G. F. (1983a). Long-term effects of early programming for the gifted/talented handicapped. Journal for the Education of the Gifted, 6, 266-278.

Karnes, M. B., Shwedel, A. M., Lewis, G. F. (1983b). Short-term effects of early programming for the young gifted handicapped child. Exceptional Children, 50, 103-109.

Karnes, M. B., Shwedel, A. M., Linnemeyer, S. A. (1982). The young gifted/talented child: Programs at the University of Illinois. Elementary School Journal, 12, 195-213.

Kaufman, A. S., Kaufman, N. L. (1982). Kaufman Assessment Battery for Children. Circle Pines, $\mathrm{MN}$ : American Guidance Services. 
Kitano, M. K., Perez, R. I. (1998). Developing the potential of young gifted children from lowincome and culturally and linguistically diverse backgrounds. In J. F. Smutny (Ed.), The young gifted child: Potential and promise, an anthology, (pp. 119-132). Cresskill, NJ: Hampton Press.

Koshy, V., Robinson, N. M. (2006). Too long neglected: Gifted young children. European Early Childhood Education Research Journal, 14, 113-126.

Kulik, J. A., Kulik, C.-L. C. C. (1984). Effects of accelerated instruction on students. Review of Educational Research, 54, 409-425.

Maker, C. J. (1986). Suggested principles for gifted preschool curricula. Topics in Early Childhood Special Education, 6, 62-73.x

Maker, C. J., \& Schiever, S. W. (2005). Teaching models in education of the gifted (3rd ed.). Austin, TX: PRO-ED.

Marland, S.P. (1972). Education of the Gifted and Talented. Report to the Congress of the United States by the US Commissioner of Education. Washington, DC: US Government Printing Office.

Mathews, F. N., Burns, J. M. (1992). A parent evaluation of a public preschool gifted program. Roeper Review, 15, 69-72.

McMillan, J. H., Schumacher, S. (2006). Research in education: Evidence-based enquiry (6th ed.). Boston, MA: Pearson and AB.

Meador, K. S. (1994). The effects of synectics training on gifted and nongifted kindergarten students. Journal for the Education of the Gifted, 18, 55-73.

Milchus, M. J., Farrah, G. A., Reitz, W. (1967). SCAMIN self-concept and motivation inventory. Dearborn Heights, MI: Person-O-Metrics.

Morgan, A. (2007). Experiences of a gifted and talented enrichment cluster for pupils aged five to seven. British Journal of Special Education, 34, 114-153.

Obrzut, A., Nelson, R. B., Obrzut, J. E. (1984). Early school entrance for intellectually superior children: An analysis. Psychology in the Schools, 21, 71-77.

Passow, H. A. (1982). Differentiated curricula for the gifted/talented. Ventura, CA: Ventura County Superintendent of Schools Office.

Proctor, T. B., Black, K. N., Feldhusen, J. F. (1986). Early admission of selected children to elementary school: A review of the research literature. Journal of Educational Research, 80, 70-76.

Quay, H. C. (1979). Classification. In H. C. Quay and J. S. Werry (Eds.), Psychopathological disorders of childhood (2nd ed., pp. 1-42). New York, NY: Wiley.

Robinson, A., Shore, B. M., Enerson, D. L. (2007). Best practices in gifted education: An evidencebased guide. Waco, TX: Prufrock Press.

Robinson, N. M. (2000). Giftedness in very young children: How seriously should it be taken? In R. C. S. Friedman and B. M. Shore (Ed.), Talents unfolding: Cognition and development (pp. 7-26). Washington, DC: American Psychological Association. 
Robinson, N. M. (2008). Early childhood. In J. A. Plucker and C. M. Callahan (Eds.), Critical issues and practices in gifted education: What the research says (pp. 179-194). Waco, TX: Prufrock Press.

Robinson, N. M., Abbott, R. D., Berninger, V. W., Busse, J., Mukhopadhyay, S. (1997). Developmental changes in mathematically precocious young children: Longitudinal and gender effects. Gifted Child Quarterly, 41, 145-158.

Robinson, N. M., Reis, S. M., Neihart, M., Moon, S. M. (2002). Social and emotional issues facing gifted and talented students: What have we learned and what should we do now? In M. Neihart, S. M. Reis, N. M. Robinson, \& S. M. Moon (Eds.), The social and emotional development of gifted children: What do we know? (pp. 267-288). Washington, DC: The National Association for Gifted Children.

Rogers, K. B. (1992). A best-evidence synthesis of the research on acceleration for gifted learners. In N. Colangelo, S. G. Assouline, and D. L. Ambroson (Eds.), Talent development: Proceedings from the 1991 Henry B. and Jocelyn Wallace national symposium on talent development (pp. 406-409). Unionville, NY: Trillium.

Rosenbusch, M. H., Draper, D. C. (1985). Gifted preschoolers: Learning Spanish as a second language. Roeper Review, 7, 209-212.

Science Research Associates Inc. (1985). Survey of basic skills (Form P). Chicago, IL: Author.

Simonsen, B., Little, C. A. (2011). Single-subject research in gifted education. Gifted Child Quarterly, 55, 158-162.

Simonsen, B., Little, C. A., Fairbanks, S. (2010). Effects of task difficulty and teacher attention on the off-task behaviour of high-ability students with behavior issues. Journal for the Education of the Gifted, 34, 245-260.

Smutny, J. F. (1999). A special focus on young gifted children. Roeper Review, 21, 172-173.

Swassing, R. H., Amidon, S. R. (1991). Single-subject research with gifted and talented students. In N. K. Buchanan \& J. F. Feldhusen (Eds.), Conducting research and valuation in gifted education: A handbook of methods and applications. New York, NY: Teachers College Press.

Terman, L. M. (1925). Genetic studies of genius: Mental and physical traits of a thousand gifted children (Vol. 1). Stanford, CA: Stanford University Press.

Thorndike, R. L., Hagen, E. P., Sattler, J. M. (1986). The Stanford-Binet Intelligence Scale: Fourth edition. Chicago, IL: Riverside.

Torrance, E. P. (1981). Thinking creatively in action and movement. Bensenville, IL: Scholastic Testing Service.

Torrance, E. P. (1998). The Torrance tests of creative thinking norms-Technical manual figural (streamlined) forms $A \&$ \& B. Bensenville, IL: Scholastic Testing Service.

Troia, G. (1999). Phonological awareness intervention research: A critical review of the experimental methodology. Reading Research Quarterly, 34, 28-52.

VanTassel-Baska, J., Schuler, A., Lipschutz, J. (1982). An experimental program for gifted four year olds. Journal for the Education of the Gifted, 5, 45-55. 
Wadlington, E., Burns, J. M. (1993). Math instructional practices within preschool/kindergarten gifted programs. Journal for the Education of the Gifted, 17, 41-52.

Walsh, R. L., Hodge, K. A., Bowes, J. M., Kemp, C. R. (2010). Same age, different page: Catering for young gifted children in prior-to-school settings. International Journal of Early Childhood, 42, 43-58.

White, K., Fletcher-Campbell, F., Ridley, K. (2003). What works for gifted and talented pupils: A review of recent research. Slough, Berkshire, England: National Foundation for Educational Research.

Ziegler, A., Raul, T. (2000). Myth and reality: A review of empirical studies on giftedness. High Ability Studies, 11, 113-136. 